\title{
Philip Kotler, Confronting Capitalism (2015) \& Democracy in Decline (2016)
}

Mark Peterson

University of Wyoming

Follow this and additional works at: https://digitalcommons.uri.edu/mgdr

Part of the American Politics Commons, Economics Commons, and the Marketing Commons

\section{Recommended Citation}

Peterson, Mark (2017) "Philip Kotler, Confronting Capitalism (2015) \& Democracy in Decline (2016)," Markets, Globalization \& Development Review. Vol. 2: No. 1, Article 7.

DOI: 10.23860/MGDR-2017-02-01-07

Available at: https://digitalcommons.uri.edu/mgdr/vol2/iss1/7

This Book Review is brought to you for free and open access by DigitalCommons@URI. It has been accepted for inclusion in Markets, Globalization \& Development Review by an authorized editor of DigitalCommons@URI. For more information, please contact digitalcommons-group@uri.edu. 
Philip Kotler, Confronting Capitalism (2015) \& Democracy in Decline (2016)

\section{Markets, Globalization \& Development Review}
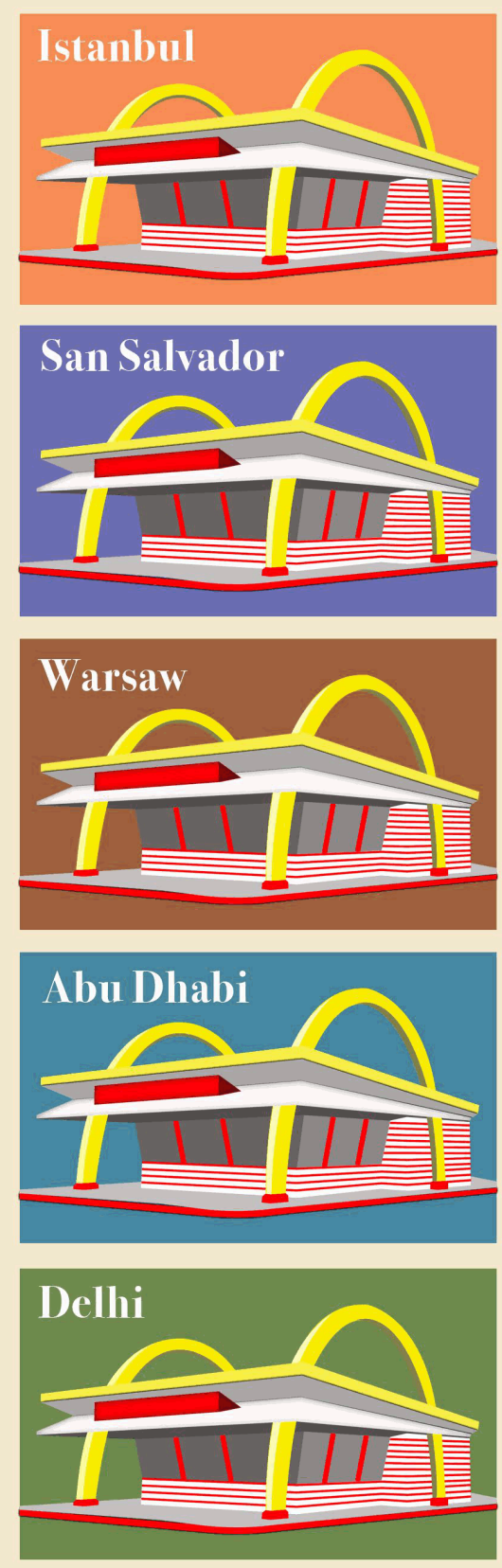
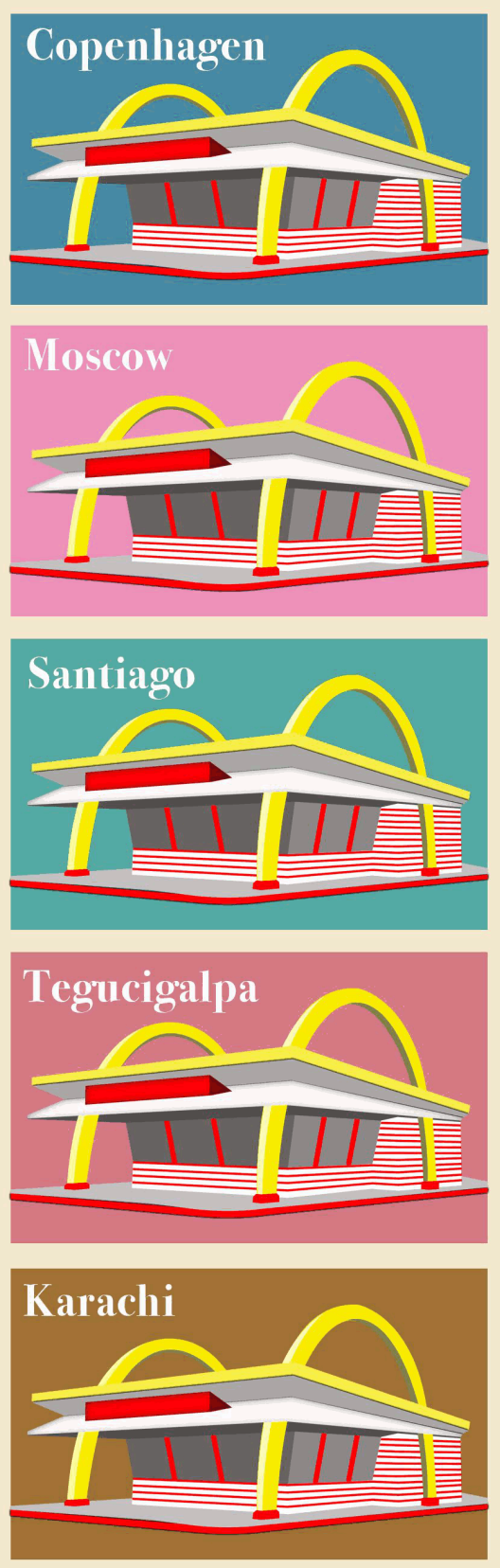
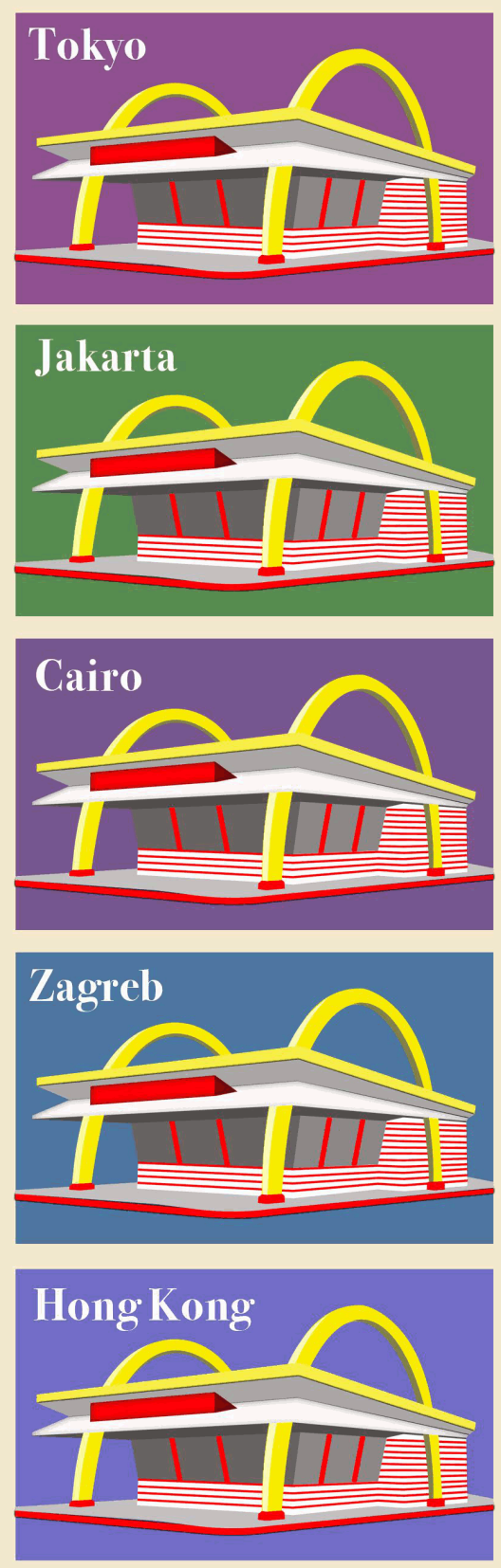

This book review is available in Markets, Globalization \& Development Review: https://digitalcommons.uri.edu/mgdr/ vol2/iss $1 / 7$ 


\section{Philip Kotler, Confronting Capitalism (2015) \& Democracy in Decline (2016)}

The year 2016 saw unexpected outcomes in national elections in two leading countries of the developed world - the UK and the US. In the Brexit vote and the election of Donald J. Trump to be US president, working class voters outside major cities queued at voting places in record numbers to express their dissatisfaction with their countries' post-Cold War trade policies. Such policies had recognized globalization as a reality of the early $21^{\text {st }}$ century and allowed - and even encouraged - offshoring or outsourcing of different parts of businesses to developing countries (see, e.g., the book by Nassimbeni and Sartor 2008, and review by Yalcin 2016) to allow these developed countries to specialize in highervalue sectors or portions of businesses.

Apple, Inc. is an example of such off-shoring - the practice of setting up some of a company's processes or services overseas, in order to take advantage of lower costs (Bobkoff 2016). Apple is also an exemplar of foreign outsourcing - obtaining goods or services from a foreign supplier, especially in place of an internal source. The designers and engineers worked in Cupertino, California - Silicon Valley - while the manufacturing was done in Taiwan and China by contract manufacturing firms, such as Foxconn, based in Taiwan but with manufacturing operations largely in mainland China.

Apple, the most profitable firm in the world, had set up its European operations to register all sales in Europe in the European Union (EU) country of Ireland - even though Apple had no offices in Ireland nor any employees (Bobkoff 2016). Instead of the $12.5 \%$ corporate tax rate most firms in Ireland pay (or $33.3 \%$ in France), Apple worked out a .005\% effective tax rate with the Irish government. In August 2016, the EU Competition Commission declared Apple owed Ireland $\$ 14.5$ billion in tax arrears because of special tax treatment. Ireland responded by saying it did not want the money (because accepting it would jeopardize its positioning as a low-profile tax haven for its preferential tax treatment extended to other global firms). Surprising turns like these spice the stories of the globalization of major corporations of the world.

Some actually go further than Apple. They "invert" by creating a subsidiary in a country like Ireland, and then transferring its legal headquarters to Ireland even though the corporate headquarters remains in the US. Pharmaceutical firm Allergan did this, but this led to the US government blocking its later proposed merger in April 2016 with Pfizer 
(which was going to have the headquarters of the merged firm in Ireland) (Merle and Johnson 2016).

Confronting such shell games across the borders of the world's countries motivated the founding of Markets, Globalization \& Development Review or MGDR (Dholakia and Atik 2016). In a globalized world, firms seek lower production costs and markets overseas while national governments become enablers of such activities - until an EU Commission or a block of voters in the heartland of the UK or the US move to the polls and say "no".

Such a backlash against globalization has much to do with capitalism, as well as democracy. An amoral capitalism emboldened by its ability to avoid wage increases and taxes has collided with the morals of an increased number of voters who are voting according to the perceived economic injustices they have endured during the rise of globalization. Such voters have seen their economic prospects dim over the last twenty years as globalization has kicked into a higher gear, rewarding a perceived "few" (the one percenters, perhaps) or citizens of countries culturally and physically distant (Stiglitz 2007).

Highly regarded marketing scholar Philip Kotler wrote two books in recent years about 1) capitalism, and 2) democracy. At the end of 2016, one can now see these two as important dimensions of the 2016 pushback against globalization. Globalization, however, makes only a cameo appearance in the book on capitalism and is not mentioned in Kotler's book on democracy. Given the turn of events in 2016, one can make a confident wager that Kotler has now begun work on an upcoming book project focused on globalization.

\section{Confronting Capitalism}

In 2015, AMACOM, the book publishing division of the American Management Association, published Confronting Capitalism: Real Solutions for a Troubled Economic System by one of marketing's most high-profiled scholars - Philip Kotler of Northwestern University (Kotler 2015). Given that Kotler's textbooks have guided the instruction of the modern business era's legions of marketing students around the world, such a critique deserves studied consideration by readers of and contributors to MGDR, and by scholars of markets and development generally.

A year earlier, French economist Thomas Piketty had his critique of capitalism published, with the title Capital in the Twenty-First Century (Piketty 2014). In this book, Piketty uses data and analysis to conclude that in today's economy, the financial rewards for being a financier exceed 
those for being an entrepreneur or an industrialist (see also, in a similar vein, the 'Finanzkapital' argument in Dholakia 2011). While Piketty focuses on the brutal economic logic driving today's economic system (which would lead rational humans to shift efforts to become financiers), Kotler focuses on externalities and on stakeholders not traditionally represented in corporate board rooms, such as the environment and the poor. In this way, Kotler's critique is aligned with the critiques offered by macromarketers over the years (Layton and Grossbart 2006).

Kotler cites fourteen shortcomings of capitalism and develops a chapter for the discussion of each. The shortcomings can be categorized into four groups: 1) poverty and economic inequality, 2) externalities, 3) lack of a long-term focus, and 4) questionable marketing outputs. Marketers might dodge responsibility for much of the shortcomings in the first three groups, because these were not considered (allowed by society to be ignored?) when marketers were doing their marketing.

Marketers, however, cannot avoid responsibility for the shortcomings of the last group, because marketers could have chosen to direct their efforts to other types of outputs. For example, Kotler cites junk food, guns, and relentless advertising as three controversial outputs of marketing systems. Not satisfied to direct criticism only on business systems, Kotler also takes aim at low-quality healthcare services and weak public education services as dubious outputs of public-sector systems. Table 1 lists the key issues raised by Kotler in the capitalism and the democracy books.

\section{Democracy in Decline}

A primary assertion of Kotler's book on the decline of democracy is that moneyed special interest groups, such as political action committees (PACs), superPACs and corporate lobbying efforts, have preempted the will of the people in the US. This can be seen in legislative gridlock in Washington, DC and voter cynicism about the aims of elected officials on satisfying these moneyed special interest groups - rather than serving the public good.

While "globalization" does not appear in the index of Democracy in Decline, "Donald Trump" does five times (His first mention is on the second page of the book's introduction). In discussing voter cynicism, Kotler presents Trump this way (Kotler 2016, p. 39):

Among those [Republican] candidates, one stood out greatly from the other candidates as an "outsider". That was Donald Trump, a vain, egotistical, and self-centered man, who commended the most news coverage and who was the most outspoken.... He attracts 
many low income and angry groups who feel downtrodden, neglected by established politicians and parties and who want a fresh voice to represent their grievances...He is hardly a person to entrust with the future of not only 350,000,000 Americans but largely the fate of the entire human race.

Kotler's preference for candidates of the Democratic Party, such as Hillary Clinton and Bernie Sanders becomes evident. For example, Kotler notes that both Trump and Sanders are "outsiders'. But while Trump's personal shortcomings are listed, Sanders' shortcoming is simply that with a Republican-controlled Congress, Sanders would have little chance of implementing his socialist legislation for healthcare, education, taxation and immigration reform.

While most everyone in the media made a mistake in their assessment of Trump's likelihood of winning a presidential election, analysis after his win suggests that Trump proved himself to be a master of branding. One observer even asserted that Hillary Clinton's brand was akin to the US Postal Service, while Trump's was more like Hooter's - a chain of bars with scantily clad waitresses serving fried foods (Fottrel 2016).

This assertion puts into relief the benefit and the weakness of Democracy in Decline. Kotler is an economist by training and this book is written in a manner that a concerned economist or a concerned citizen would write. Kotler's fame and notoriety around the world, however, is based on his success as a marketing scholar and author. Branding is the very thing featured prominently in Kotler's marketing textbooks which have sold millions of copies around the world. It is highly likely that Trump himself or his key staffers know Kotler's name and learned marketing by studying Kotler's books. In other words, Trump's success suggests he and his staffers better understood the marketing knowledge Kotler has so effectively promoted in the last fifty years.

I tell my marketing students that one of the scariest things one can experience in business is seeing much more effective marketing used against you and your organization in a competitive setting. It is difficult to dodge or to turn to one's advantage. It doesn't go away. Its undeniable effect can be heard in the quieter cash registers and can be seen in the empty offices where co-workers once labored with you.

Trump positioned himself as the disrupter (Fottrel 2016). His tirades, tweets and public insults of other candidates reinforced this strongly. By comparison, Clinton brought pop-stars, such as Katy Perry and Beyoncé, to many of her campaign appearances, but doing this did 
not excite those inclined to vote for Clinton, as much as Trump's approach did with those inclined to vote for him.

Table 1: The Fourteen Issues Addressed in the Two Books by Philip Kotler

\begin{tabular}{|c|c|c|}
\hline & $\begin{array}{l}\text { Confronting Capitalism: } \\
\text { Real Solutions for a Troubled } \\
\text { Economic } \\
\text { System }\end{array}$ & $\begin{array}{l}\text { Democracy in Decline: } \\
\text { Rebuilding Its Future }\end{array}$ \\
\hline 1 & The persistence of poverty & $\begin{array}{l}\text { Low voter literacy, turnout } \\
\text { and engagement }\end{array}$ \\
\hline 2 & Income inequality on the rise & Shortage of highly qualified \\
\hline 3 & Workers under siege & $\begin{array}{l}\text { Blind belief in American } \\
\text { exceptionalism }\end{array}$ \\
\hline 4 & $\begin{array}{l}\text { Job creation in the face of } \\
\text { growing automation }\end{array}$ & $\begin{array}{l}\text { Growing public antipathy toward } \\
\text { government }\end{array}$ \\
\hline 5 & $\begin{array}{l}\text { Companies not covering } \\
\text { their "social costs" }\end{array}$ & $\begin{array}{l}\text { Two-party gridlock preventing } \\
\text { needed legislation }\end{array}$ \\
\hline 6 & Environment exploitation & $\begin{array}{l}\text { Growing role of money in } \\
\text { politics }\end{array}$ \\
\hline 7 & $\begin{array}{l}\text { Business cycles and } \\
\text { economic instability }\end{array}$ & Gerrymandering \\
\hline 8 & $\begin{array}{l}\text { The dangers of narrow } \\
\text { self-interest }\end{array}$ & $\begin{array}{l}\text { Primaries leading candidates to } \\
\text { adopt more extreme positions }\end{array}$ \\
\hline 9 & $\begin{array}{l}\text { The debt burden and } \\
\text { financial regulation }\end{array}$ & $\begin{array}{l}\text { Continuous conflict between the } \\
\text { President and Congress }\end{array}$ \\
\hline 10 & How politics subverts economics & $\begin{array}{l}\text { Continuous conflict between } \\
\text { the Federal and State } \\
\text { Governments }\end{array}$ \\
\hline 11 & $\begin{array}{l}\text { Capitalism's short-term } \\
\text { Orientation }\end{array}$ & $\begin{array}{l}\text { The Supreme Court's } \\
\text { Readiness to revise legislative } \\
\text { actions }\end{array}$ \\
\hline 12 & $\begin{array}{l}\text { Questionable marketing } \\
\text { Outputs }\end{array}$ & $\begin{array}{l}\text { The difficulty of passing new } \\
\text { amendments }\end{array}$ \\
\hline 13 & $\begin{array}{l}\text { Setting the right GDP growth } \\
\text { Rate }\end{array}$ & $\begin{array}{l}\text { The difficulty of developing a } \\
\text { sound foreign policy }\end{array}$ \\
\hline 14 & $\begin{array}{l}\text { Creating happiness as well } \\
\text { as goods }\end{array}$ & $\begin{array}{l}\text { Making government agencies } \\
\text { more accountable }\end{array}$ \\
\hline
\end{tabular}

One of Kotler's key assertions that lax campaign finance laws would tilt elections to the candidate who raised the most money proved not to be correct in the 2016 presidential election. Bloomberg Politics 
reported at the end of October 2016 that Clinton raised $\$ 413.5$ million dollars more than Trump - $\$ 866.6$ million to $\$ 453.1$ million (Allison et al 2016). In other words, Clinton focused on the economics of the election and almost raised twice as much cash as Trump - but lost to Trump who focused on the marketing dimension of his candidacy.

\section{Both Books}

Kotler's Democracy in Decline and Confronting Capitalism serve readers well by offering a route to become better informed on issues confronting business and society. In this way, these books benefit readers like his textbooks have done. They have breadth, but because of the number of issues undertaken by Kotler and space limitations of his publishers, depth is frequently lacking on these issues. (In both books, Kotler addresses 14 issues which are presented in Table 1).

However, for readers who want to quickly obtain an overview of issues related to capitalism or to the functioning of democracy today, these books will have value. The books offer generally well-grounded points about capitalism or democracy. One's scholarship or one's talk at the next dinner party would be more insightful as the result of reading these books.

Basketball great Michael Jordan (the greatest of all time, perhaps) left basketball for a year and a half at the peak of his NBA career to pursue a new career in professional baseball (Jordan 1998). He finally returned to NBA basketball from his playing sojourn in minor league baseball-according to Jordan, for the love of the game of basketball. In fact, fans came to see his team because of his accomplishments in basketball, rather than in baseball.

I see similarity in Jordan's story and Kotler's. Most who buy either of these two books will do so because of Kotler's reputation that he built in marketing scholarship and marketing teaching and marketing textbook writing. In Democracy in Decline, "marketing" is never mentioned explicitly. In Confronting Capitalism, "marketing" receives more thorough treatment including marketing's role in environmental degradation, which Kotler has also addressed in the Journal of Macromarketing (Kotler 2011). Kotler has also written compellingly about marketing's role in alleviating poverty (Achrol and Kotler 2016).

Because of Kotler's willingness to address marketing, per se, in Confronting Capitalism, I believe this book succeeds more than Democracy in Decline. In writing about the American political system and its needs for reform, Kotler is in a new realm - much like Michael Jordan was in baseball. 
Looking to the future, readers in academia and outside of it would benefit from Kotler giving full treatment to marketing's role in 1) globalization, as well as 2) electioneering in modern democracies. The world needs timely and thorough treatment of these topics now. Kotler would do his fans right to return to his game - marketing - like Jordan did - if for no other reason than for the love of the game.

Potentially, Kotler can speak with authority like few others when it comes to marketing. Like other fans, I look forward to Kotler's return to the game with the announcement of his next book (on globalization or election marketing) signaled to the world with a statement like Jordan's when he returned in mid-season of 1995 - "I'm back." 


\section{References}

Achrol, Ravi, and Kotler, Philip (2016), "Marketing's Lost Frontier: The Poor", Markets, Globalization \& Development Review 1 (1), Article 3.

Allison, Bill, Rojanasakul, Mira, Harris, Brittany and Sam, Cedric (2016), "Tracking the 2016 Presidential Money Race," Bloomberg Politics. (accessed November 25, 2016), [available at https://goo.gl/hX6HIB]

Bobkoff, Bob (2016), "What just happened to Apple, explained", Business Insider, August 30, 2016, (accessed November 25, 2016), [available at https://goo.gl/8gGDmq]

Dholakia, N. (2011), "Finanzkapital in the twenty-first century", critical perspectives on international business, 7 (1), 90-108.

Dholakia, Nikhilesh and Atik, Deniz (2016), "Markets, Globalization, Development: Charting the Intersections of Three Multipolar Concepts", Markets, Globalization \& Development Review: 1 (1), Article 1.

Fottrell, Quentin (2016), "How TV reality star Donald Trump won the election with his 'disruptive' brand", MarketWatch, November 11, 2016, (accessed November 25, 2016), [available at https://goo.gl/w6Rf3V]

Jordan, Michael (1998), For the Love of the Game: My story. Edited by Mark Vancil. Crown, 1998.

Kotler, Philip (2011), "Reinventing marketing to manage the environmental imperative." Journal of Marketing 75 (4), 132-135.

Kotler, Philip (2015), Confronting Capitalism: Real Solutions for a Troubled Economic System. New York: American Management Association.

Kotler, Philip (2016), Democracy in Decline: Rebuilding Its Future. SAGE.

Layton, Roger A. and Grossbart, Sanford (2006), "Macromarketing: Past, Present, and Possible Future", Journal of Macromarketing, 26 (2), 193-213.

Merle, Renae and Johnson, Carolyn Y. (2016), "Pfizer, Allergan call off $\$ 160$ billion merger after U.S. moves to block inversions", Washington Post, April 6, 2016, (accessed November 25, 2016), [available at https://goo.gl/uXkXIn ].

Nassimbeni, Guido and Sartor, Marco (2008), Sourcing in India: Strategies and experiences in the land of service offshoring. New York: Palgrave Macmillan. 
Piketty, Thomas (2014), Capital in the Twenty-First Century. Harvard University Press.

Stiglitz, Joseph E. (2007), Making Globalization Work. WW Norton \& Company.

Yalcin, Mehmet G. (2016) "Nassimbeni and Sartor, Sourcing in India (2008)", Markets, Globalization \& Development Review: 1 (1), Article 8. 